\title{
The Effect of Word Wall Strategy on Students' Vocabulary Achievement at SMP Negeri 5 Pematangsiantar in the Academic Year 2018/2019
}

\author{
Rohdearni Wati Sipayung \\ FKIP, Simalungun University (USI), Simalungun, Indonesia \\ dearsipayunk@gmail.com
}

\begin{abstract}
English is an international language. This research is aimed to improve students' vocabulary achievement in antonym of adjective to the seventh grade of SMP Negeri 5 Pematangsiantar in academic year 2018/2019. The material which will be tested is vocabulary in antonym of adjective. This study was an action research study. Statement of the problem of this research is "how is the students" vocabulary achievement improved by using word wall strategy?" The objective in this research is to know the students' vocabulary achievement by using word wall strategy. The samples of this research were 32 students of VII-3 class. The data were form of quantitative data. The quantitative data were collected from giving them test (matching test) to see the improvement of the students'vocabulary achievement by score of pre-test and post-test. The result of the students' progress during the teaching learning process by using word wall strategy was good. The students' achievement increased from giving them pre-test and post-test. It could be seen the average of the score of pre-test and post-test, the result of pre-test was 42, 58 while post-test was 91, 61. The different of the score was significant. It means that using Word Wall strategy in teaching can improve the students'vocabulary achievement. Finally the researcher suggests using this strategy in teaching learning process especially in teaching vocabulary.
\end{abstract}

Keywords: word wall strategy; antonym of adjective; vocabulary achievement

\section{Introduction}

Language is important because it is one of the main ways to communicate and interact with other people around us. It keep us in contact with other people. English is an example for the importance of a language because it is the international language and has become the most important language to people in many parts of the world. English is also an important subject in school. It plays a vital role for the students when they want to continue their education to higher level. In the process of English learning, the most important component is teacher's attitudes towards English learning. A teachers performance can be seen in his/her behavior towards his/her work of teaching. The factors affecting the performance of teachers are attitude, method of teaching, classroom management, and motivation. Students strongly depend on their teacher's skill to stimulate 
interest in improving their English language skills. Facilities is also a component that affects the quality of learning process.

Learning vocabulary is important for the learners, as Thornbury (2002:13) says "Without grammar very little can be conveyed, without vocabulary nothing can be conveyed." It means that mastering vocabulary is needed by the students because they will hard to say something without mastering grammar and without mastering vocabulary there is nothing to say. There are many problems in learning vocabulary by the students, some of them still difficult to memorize unfamiliar words that they heard or read in the text. They have difficulties in understanding or comprehending the meaning of unfamiliar words. They do not know the meaning when the teacher explains the material with English. The students could not pronounce the word correctly. The students tended to pronounce the letters of the words and the students found difficulties in speeling the words. The students found difficulties in memorizing the meaning of the words. The students get difficulties such as they did not know how to recognize speeling a word and find the meaning of vocabulary based on the text, finding synonym and antonym.

\section{Review of Related Literature}

\subsection{Teaching English}

Teaching is an activity to transfer information, knowledge, skills, attitudes and ideas from teacher to students. Teaching can changes in behavior and and growth of students. Teaching English as Foreign Language (TEFL) refer to teaching the English to students with different first languages. English teaching whould therefore be 'child centered' only in the very limited sense that all good teaching is child centred-that it engages the interest and efforts of the pupils. Improvement in pupils' powers of speaking and listening would be achieved by improving their literacy.

In teaching English there are four kinds of language skill; they are listening, speaking, reading, and writing. There are some language components such as speeling, grammar, and vocabulary that should be taught to support the language skill development. And the most important is Vocabulary. With vocabulary we can make sentences use grammar. The most important thing in teaching English is Vocabulary. According (Scott Thornbury 2002:13) "Without grammmar very little can be conveyed, without vocabulary nothing can be conveyed? This is how the linguist David Wilkins summed up the impotance vocabulary. His view is echoed in this advice to students from a recent coursebook (Dellar $\mathrm{H}$ and Hocking D,Innovations,LTP).

\subsection{Definition of Vocabulary}

Vocabulary is one of language aspects that has to be learned when people are learning a foreign language. By learning new vocabulary, learners can improve their listening, speaking, reading, and writing skills. Vocabulary is very needed in language acquisition. Vocabulary is one of the components of language. Orchads and Renandya (2002:255) in journal Chusnul Urbayati tahun 20017 say "Vocabulary is a core of component of language proficiency and provides much of the basis for how well learners 
speak, listen, read, and write." It means that vocabulary is a crucial element which influences the four English skills that are Listening, Speaking, Reading, and Writing. Thus, the students must have a lot of vocabularies to support their skill.

Vocabulary is a total number or list of words that have meaning and are indispensable to express our thoughts. A person is expected to continue to develop their vocabulary in order to continue to communicate effectively, both in oral and written form. A good understanding of vocabulary will also help students be succesfull in their english test. Vocabulary is very important to learn because when student have a limited vocabulary they are not able to express their thoughts accurately and answer question in their test. If students do not know how to improve their vocabulary, they will most likely lose interest in learning English.

Vocabulary is an essential component in foreign language learning. In addition, vocabulary is central to the learning of foreign language especially at secondary level to enrich their language. In EFL classroom, vocabulary is needed to express meaning and to convey thoughts through both receptive skill and productive skill. According to Nation (1990:2) Vocabulary is that both learners and teacher see as a very important element in language learning. It means that vocabulary holds are very important role in certain language and the students should master adequate number of vocabulary in order to perform the language well. Napa (1991:6) states that vocabulary is one of components of language and there is no language that exists without words. Vocabulary is a list of words with their own messages which are used in a language to represent meaning. It refers to every single word which is understood and used to convey ideas.

There are four different kinds of vocabularies according to Montgomery (2007). One is speaking vocabulary, the words we use in everyday talk at home or at work. Another is writing vocabulary, the words we use in notes, letters, reports or any other kind of writing. It is somewhat larger because you have time to stop and find the right word. Listening vocabulary is still larger. It is consists of words that we understand when we hear them. Many of these words we would never use in speaking or writing. Reading vocabulary is the largest. It consists of all the words we recognize when we see them. Our vocabularies continue to grow as we meet new words in our studies, in newspaper, and on radio and TV Programs.

Our vocabulary study seemed consistently to revolve around the dull routines of looking uo defining and memorizing words and using them in sentences. Such as instructional pattern resulted in meaningless, purposeless activity end in itself, rather than a means to an end. Although there was nothing inherently wrong with looking up, defining and memorizing words and using them in sentences. The approach itself was to narrow for us to learn words in depth instead. We memorized definitions to pass the Friday quiz and forgot them on Saturday. Having students learn lists of words isbased on the ill founded conclusion that the acquisition of vocabulary is separate from the development of ideas and concepts in a content area. Teaching vocabulary often means assigning a corpus of words rather than exploring words meanings and relationships that contribute the student's conceptual awareness and understanding of a subject. Once teacher's clarity the relationship between words and concepts, they are receptive to instructional alternatives.

There are several different types of vocabulary, such as listening vocabulary, speaking vocabulary, reading vocabulary, and writing vocabulary. 
1. Listening vocabulary

Listening vocabulary is all the words that can recognize when listening to speech. This vocabulary is aided in size by context and toneof voice.

2. Speaking vocabulary

Speaking vocabulary is all the words which can use in speech. Due to the spontaneous nature of the speaking vocabulary- words are often misused. This misused- though slight and unintentional- may be compensated by facial expressions, tone of voice, or hand gestures.

3. Reading vocabulary

Reading vocabulary is all the words that can recognize when reading.

4. Writing vocabulary

Writing vocabulary is all the words that can employ in writing.

\subsection{Antonym of adjective}

In general, an antonym (pronounced an-tuh-nim) is a word that has the exact opposite meaning of another word. In common parlance, they are called 'opposites'. Here there are some definitions of antonym, namely:

1. An antonym is one of a pair of words with opposite meanings. Each word in the pair is the antithesis of the other. A word may have more than one antonym.

2. Antonym is a word thet expresses a meaning of another word, in which case the two words are antonyms of each other.

3. An antonym is a word having a meaning opposite to that of another word, such as hot and cold, short and tall.

4. An antonym is the antonym of synonym. Adjective: antonymous. Another word for antonym is counterterm.

5. Antonymy is the sense relation that exists between words which are opposite in meaning. Edward Finnegan defines antonymy as "a binary relationship between terms with complementary meanings".

6. An antonym is a word that has the opposite meaning of another. For example: Bad is an antonym of good, ugly is an opposite of beautiful.

However, it is not always the case that one word has just one antonym. There are some antonyms of good: bad, badness, corrupt, evil, evilness, malicious, sour, and wicked. The point is that good, like many words, can be a noun or an adjective, so its antonyms will be a mix of nouns and adjective too. The following are examples of antonym in adjective.

Table 1.Antonym of Adjective

\begin{tabular}{|c|c|}
\hline Adjective & Antonym \\
\hline Beautiful & Ugly \\
Clean & Dirty \\
Lazy & Diligent \\
Long & Short \\
Happy & Sad \\
Good & Bad \\
Quick & Slow \\
Cold & Hot \\
\hline
\end{tabular}


Far

Expensive

Easy

Wet

Humble

Tall

Large

Noisy

Cruel

Magnificent Full

Strong

Dangerous

Hard

Good

Exciting

Cool

Love

Happy

Laugh

Succeed

Wise

Remember

Fat

Generous

Genuine

Harsh

Healthy

Heavy

High

Hungry

Young

Quite

Patient

Rude

Sharp

Simple

Solid

Smile

Sweet

Swift

Tame

Tardy

Temporary

Thick

Together

Tough

Triumph
Near

Cheap

Difficult

Dry

Arrogant

Short

Small

Quiet

Merciful

Unimpressive

Empty

Weak

Safe

Easy

Evil

Dull

Warm

Hate

Miserable

Cry

Fail

Foolish

Forget

Skinny

Stingy

Fake

Mild

Sick

Light

Low

Full

Old

Noisy

Impatient

Polite

Dull

Complicated

Liquid

Frown

Sour

Slow

Wild

Early

Permanent

Thin

Apart

Tender

Fail 


\begin{tabular}{|c|c|} 
True & False \\
Ugly & Pretty \\
Unique & Ordinary \\
Usefull & Useless \\
Usually & Rarely \\
Villain & Hero \\
Violent & Gentle \\
Wide & Narrow \\
Win & Lose \\
Zeal & Listless \\
\hline \multicolumn{2}{|c|}{ Source: Ai Siti Djamilah on Learning More English 1 (2011) }
\end{tabular}

The following is the picture of word wall about antonym of adjective.

Figure 1. Antonym of Adjective

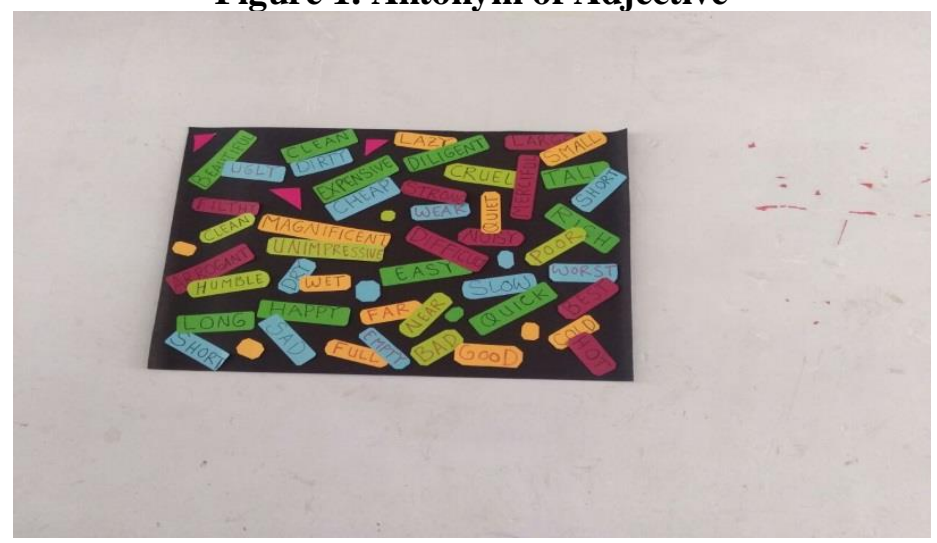

\subsection{Definition of Word Wall Strategy}

A Word Wall is a literacy tool composed of an organized collection of words which are displayed in large visible letters on a wall, bulletin board, or another display surface in a classroom. It helps to facilitate students to improve their vocabulary. It is definitely adaptable to any subject and any grade level and has been proven to be extremely effective learning and teaching tools (Burden, 2011). If teachers have their own classrooms, they can create word walls. Word walls come in many varieties. They are most often arranged alphabetically, but can just as easly be arranged by topic or classes of word. Pictures can also be included next to words. This media can be designed to improve individual or group activities that can involve students in making process. By using word wall method is expected that students could increase understanding of the English vocabulary without depend on the use of a dictionary or even the meaning of the word given by the teacher. The use of the Word Wall Strategy in teaching vocabulary can lead the students to actually use the language. As they improve their knowledge of words and their meanings in different contexts, they build confidence and become more active learners.

Word Walls is a collection of words displayed somewhere in the classroom that can be vocabulary significant to the students. "They serve as an excellent source of information for students attempting to analyze unknown words, spell unfamiliar words, or define new 
vocabulary" (Yates, Cuthrell, \& Rose, 2011).Word Walls have been a long standing strategy to assist students in their vocabulary. When students are facing new words, a teacher is likely to place the word up on the word wall and in some cases, group them with similar words. Teachers have been expanding the word wall concept to include online word walls, interactive word walls, and now a three-dimensional picture model wall."Using threedimensional picture models to represent words gives students a lasting correlation between pictures and the words they illustrate" (Zivkovich, 1997).

\section{Methodology of Research}

\subsection{Research Design}

Research design in this study was to seek and to answer the question of the study "How could the use of Word Wall as a teaching strategy can help students in students' vocabulary achievement. This research is conducted by using experimental design. The experimental class divided be two steps, first pre-test where the researcher improve their vocabulary in antonym of adjective without gives word wall and gives a test in the end namely pre-test. And the second, post-test where the researcher to improve their vocabulary in antonym of adjective with applying word wall and in the end the teacher gives a test namely post-test.

\subsection{Population and Sample}

\subsubsection{Population}

The overall population is a number of the respondents research (Arikunto, 2006:130). The population of this study is class VII at SMP Negeri 5 Pematangsiantar, in which total of class VII are nine classes. These follow the number of researchers' population.

Table 2. Population of the Research

\begin{tabular}{|c|c|}
\hline Classes & Number of Students \\
\hline VII-1 & 32 \\
\hline VII-2 & 32 \\
\hline VII-3 & 32 \\
\hline VII-4 & 32 \\
\hline VII-5 & 32 \\
\hline VII-6 & 32 \\
\hline VII-7 & 32 \\
\hline VII-8 & 32 \\
\hline VII-9 & 32 \\
\hline Total Population & 288 \\
\hline
\end{tabular}

\subsubsection{Sample}


According to Arikunto, (2010: 174) sample is a small unit of individual that exactly include in a research from the calculation, it is known that the number of population is 288 students. The researcher choose one class it is VII_6 because when the researcher did teacher training in that school, the researcher's teacher training consultant is the guardian class teacher of VII_6 so, the researcher will takes VII-6 as the sample that consists of 32 persons.

\subsection{Instrument of collecting the data}

\subsubsection{Test}

Instrument is the tool that is used to get the data in this research is pre-test and posttest. The pre-test and the post-test were in the same form. The test is objective test in a form of matching test using adjective of antonym. Instrument of this research are taken from the book "Learning More English 1 for Grade VII Junior High School".

\subsection{Technique of collecting data}

To collect the data of this research, the researcher used method of collection as follow:

1. Pre-test

Pre-test was done before implementation of Word Wall Strategy and before treatment process. The researcher is known of the students' ability in vocabulary improvement.

2. Treatment

After pre-testing, the samples were treated /taught by using Word wall strategy. They tested using be Post-test by using same item as pre-test.

3. Post-test

Post-test is implemented after using Word wall strategy. The Researcher gives the test to all of students as the sample and asks them to do the test individually carefully on certain given time. The students results were treat as the data of the research. And the test is similar to the pre-tes.

\subsection{Data and source of the data}

In this research, the data consists of pre-test and post-test. The purpose of the research knows the result of the use of word wall strategy to improve students' vocabularies achievement for class VII-6 at SMP Negeri 5 Pematangsiantar and the sample for this research there are 32 persons. And the text that researcher used in Post-test and Pre-test researcher taken from book "Learning More English 1 for Grade VII Junior High School".

\subsection{Scoring of the Test}

In scoring the test, this study will use score ranging from $0-100$ by counting the correct answer and applying this formula:

Where:

$$
S=\frac{R}{N} \times 100 \%
$$

$S=$ Score of the test

$R=$ number of the correct answer

$N=$ number of the question 
To get the average score, the researcher use the mean score as the following:

$\overline{\mathrm{X}}=\frac{\sum \times}{N}$ (Arikunto, 2010: 343)

Where,

$\bar{x}=$ Average score

$\mathrm{N}=$ totally of students

$\sum \times=$ Total of reading scores. following:

To get the average score, the researcher use the mean score as the $\overline{\mathrm{X}}=\frac{\sum \times}{N}$ (Arikunto, 2010: 343)

Where,

$\bar{x}=$ Average score

$\mathrm{N}=$ totally of students

$\sum \times=$ Total of reading scores.

\subsection{Technique of Analyzing of the data}

To analyze the data, there are pretest and post test and after that looking for the total score. According to Arikunto, to analyze the data, this research will use analyzing of the five categories "very good", "good", "enough", "low", "very low"(Arikunto). The table of scoring the five categories:

Table 3. The categories of students' vocabulary achievement

\begin{tabular}{|c|c|}
\hline CATEGORIES & SCORES \\
\hline VERY GOOD & $90-100$ \\
GOOD & $70-80$ \\
ENOUGH & $50-60$ \\
LOW & $30-40$ \\
VERY LOW & $0-20$ \\
\hline
\end{tabular}

Source: Ashima Situmorang Thesis with Modification (2015)

\section{Discussion}

This chapter discusses about the result of the research, which consists of data analysis, the level of the students' ability, research finding and discussion. The writer has given the test as the instrument to measure or to know the effect of word wall media strategy on students' vocabulary achievement. In collecting the data, the researcher gives the test to the students at the seventh grade students of SMP Negeri 5 Pematangsiantar and the test is matching test about antonym of adjective test in objective test forms. Then, the writer analyzes the score of the students by using the formula as stated in chapter III.

\subsection{Data Analysis}


When the researcher did the observation in that class of experimental, on the next day the researcher did the research with begin the pre-test. In this step, researcher taught the antonym of adjective to students experimental. The examples of antonym in adjective and the meaning of the words. Researcher gave the familiar words and asked to the students about adjective and the students learned it and try to translate and found the opposite of the words. And the end of learned antonym of adjective, the researcher give a test to measure the students' ability, the test is Matching test. The following text of adjective that used by researcher in pre-test step.

Table 4. The Result of Pre-test

\begin{tabular}{|c|c|c|c|}
\hline No. & Name & Score & Categories \\
\hline 1 & Anggun $\mathrm{N}$ & 80 & Good \\
\hline 2 & Bastian Pebri & 40 & Low \\
\hline 3 & Caroline Oliv & 80 & Good \\
\hline 4 & Chyntia H & 60 & Enough \\
\hline 5 & Daniel S & 30 & Low \\
\hline 6 & Daniel M & 40 & Low \\
\hline 7 & Dapot Masron & 40 & Low \\
\hline 8 & Dimas Wahyu & 20 & Low \\
\hline 9 & Frety Shofia & 40 & Low \\
\hline 10 & Grace Evelyn & 40 & Low \\
\hline 11 & Gresy Purba & 50 & Enough \\
\hline 12 & Imel Sopia S & 40 & Low \\
\hline 13 & Jhona Agtriel & 30 & Low \\
\hline 14 & Kristopel S & 20 & Low \\
\hline 15 & Lidya Olivia & 40 & Low \\
\hline 16 & Lionel S & 50 & Enough \\
\hline 17 & Mikhael P & 40 & Low \\
\hline 18 & Nico Prayoga & 30 & Low \\
\hline 19 & Partogi J & - & - \\
\hline 20 & Pranata Purba & 30 & Low \\
\hline 21 & Ricad Agus K & 40 & Low \\
\hline 22 & Riskia T & 50 & Enough \\
\hline 23 & Ruth Marbun & 30 & Low \\
\hline 24 & Selvia Erna & 60 & Enough \\
\hline 25 & Siska A & 40 & Low \\
\hline 26 & Stiven Natan & 40 & Low \\
\hline 27 & Timothy A & 40 & Low \\
\hline 28 & Titian Dhea & 30 & Low \\
\hline 29 & Tri Wanti N & 30 & Low \\
\hline 30 & Winda Yuniar & 40 & Low \\
\hline 31 & Yemima R & 60 & Enough \\
\hline \multirow[t]{2}{*}{32} & Yolif M & 60 & Enough \\
\hline & TOTAL & 1320 & \\
\hline
\end{tabular}




\begin{tabular}{|l|l|l|l|}
\hline & AVERAGE & 42,58 & LOW \\
\hline
\end{tabular}

From the table above the result of pre-test, researcher explains that the sample for this research there are 31 persons, 1 person is absent. And after researcher did the test, there are 18 students got a low score and there are 2 students got a very low score. And the average for the list of score in the pre-test step is 42,58 and categories that using is LOW. These following the result table from the first step, Based on the table above, the percentage of students who are able in the pre-test step.

Table 5. Categories in Pretest

\begin{tabular}{|c|c|}
\hline Categories & Number of Students \\
\hline Very Good & - \\
\hline Good & 2 \\
\hline Enough & 9 \\
\hline Low & 18 \\
\hline Very Low & 2 \\
\hline $\mathrm{P}=\frac{11}{31} \times 100 \%=35 \%$ \\
\hline
\end{tabular}

Where:

26: the number of students that have (very good, good, and enough)

31: the number of all students (sample).

After the pre-test was done, the researcher does the treatment. In this part researcher gives Word Wall about Antonym of Adjective. Researcher teaches opposite of Adjective with using Word Wall to help students reminded the words. After the Researcher give word wall, for the next day the teacher teaches about adjective and antonym again, then the researcher gives a test (post-test) based on the words in objective test in matching test form same with pre-test. The result of that test in that table below:

Table 6. The result of Post-test

\begin{tabular}{|c|c|c|c|}
\hline No. & Name & Score & Categories \\
\hline 1 & Anggun N & 90 & Very good \\
\hline 2 & Bastian Pebri & 90 & Very good \\
\hline 3 & Caroline Oliv & 100 & Very good \\
\hline 4 & Chyntia H & 100 & Very good \\
\hline 5 & Daniel K S & 90 & Very good \\
\hline 6 & Daniel M & 100 & Very good \\
\hline 7 & Dapot Masron & 80 & Good \\
\hline 8 & Dimas Wahyu & 90 & Very good \\
\hline 9 & Frety Shofia & 100 & Very good \\
\hline 10 & Grace Evelyn & 90 & Good \\
\hline 11 & Gresy Purba & 100 & Very good \\
\hline 12 & Imel Sopia S & 100 & Very good \\
\hline 13 & Jhona Agtriel & 90 & Very good \\
\hline 14 & Kristopel S & 80 & Good \\
\hline
\end{tabular}




\begin{tabular}{|c|c|c|c|}
\hline 15 & Lidya Olivia & 100 & Very good \\
\hline 16 & Lionel S & 90 & Very good \\
\hline 17 & Mikhael P & 80 & Good \\
\hline 18 & Nico Prayoga & 80 & Good \\
\hline 19 & Partogi J & 90 & Very good \\
\hline 20 & Pranata Purba & 90 & Very good \\
\hline 21 & Ricad Agus K & - & - \\
\hline 22 & Riskia T & 85 & Good \\
\hline 23 & Ruth Marbun & 80 & Good \\
\hline 24 & Selvia Erna & 90 & Very good \\
\hline 25 & Siska A & 100 & Very good \\
\hline 26 & Stiven Natan & 90 & Very good \\
\hline 27 & Timothy A & 90 & Very good \\
\hline 28 & Titian Dhea & 100 & Very good \\
\hline 29 & Tri Wanti N & 90 & Good \\
\hline 30 & Winda Yuniar & 100 & Very good \\
\hline 31 & Yemima R & 100 & Very good \\
\hline \multirow[t]{3}{*}{32} & Yolif M & 70 & Good \\
\hline & TOTAL & 2840 & \multirow[b]{2}{*}{ VERY GOOD } \\
\hline & AVERAGE & 91,61 & \\
\hline
\end{tabular}

As we seen the table above the result of post-test, researcher explains that there are 31 persons the sample of this research and 1 persons is absent. And there is no students got an enough score. And the average for the list of score in the post test step is 91,61 and categories that using is VERY GOOD level. Its means that the students' vocabularies achievement at seventh six grade of SMP Negeri 5 Pematangsiantar was increased after being taught by using Word Wall Strategy. These following the result table from the first step, Based on the table above, the percentage of students who are able in the post test step,

Table 7. Categories in Post test

\begin{tabular}{|c|c|}
\hline Categories & Number of Student \\
\hline Very Good & 25 \\
\hline Good & 6 \\
\hline Enough & - \\
\hline Low & - \\
\hline Very Low & - \\
\hline & $\mathrm{P}=\frac{31}{31} \times 100 \%=100 \%$ \\
\hline
\end{tabular}

Where:

31: the number of students that have (very good, good, and enough)

31: the number of all students (sample).

\section{Conclusion}


There are some conclusion according to the result of implementing preexperimental research at seventh grade of SMP Negeri 5 Pematangsiantar.

1. The score of the students' vocabularies achievement in antonym of adjective at grade VII-6 OF SMP Negeri 5 Pematangsiantar in academic year 2018/2019 before using word wall strategy is 1320 , the mean is $42,58(35 \%)$. And after busing word wall strategy students' score is 2840 , the mean is 91,61 with $100 \%$.

2. The implementation of word wall strategy improved the students' vocabulary achievement. And from the average of pre-test and post-test scores showed from the students who were taught by using word wall strategy than the students who were taught without word wall strategy.

\section{References}

Arikunto, Suharsimi . 2010. Prosedur Penelitian Suatu Pendekatan Praktik (Revisi 2010). Jakarta: Rineka Cipta. 2009. Prosedure Penelitian Suatu Pendekatan Praktik. Jakarta: Rineka Cipta.

Ashima, Situmorang. 2015. The Efectiveness of Cooperative Learning Talking Stick on Students' Reading Comprehension at SMP Swasta Taman Asuhan Pematangsiantar. Thesis. Universitas Simalungun.

Burden, Karen. (2011). Literacy Light: Word Walls. Newletter. From http://fvhs.wcpss.net/current_forms_documents/Literacy Light/literacy Light 8 FVHS.pdf[12/09/2014].

Brummit, J. 2012. 10 Great Word Wall Strategies for Classrooms. Retrieved on 20 July 2014. From:http:/www.k12reader.com/10-great-word-wall-strategies-forclassrooms.

Chusnul Urbayati Journal Bahasa inggris Universitas Nusantara PGRI Kediri. Simki pedagogia vol.01 No.02 Tahun 2017

Cronsberry, J. 2004. Word Walls: A support for literacy in secondary school classroom. Retrieved on December $14^{\text {th }} \quad 2014$ from http://curriculum.org/storage/258/1334340769/World Walls A Support for literacy in secondary school classrooms pdf

English Education: e-Journal Bahasantodea, Teaching vocabulary. Volume 3 Nomor 2, April 2015 hlm 23-35. ISSN: 2302-2000

Harmer, J.2007. How to Teach English. Harlow: Longman Pearson Education Ltd Longman Journal of English Education Department of UIN Alauddin Makasar, volume I, Number 02, Desember 2015

Montgomery, Judy K. (2007). The Bridge of Vocabulary: Evidence Based Activities for Academic Success. USA: NCS Pearson Inc.

Nation, I.S.P. 2001. Learning Vocabulary in Another Language. Cambridge University Press. 